At-Tijaroh : Jurnal Ilmu Manajemen dan Bisnis Islam

Volume 5 Nomor 1 Ed. Jan - Juni 2019 : Hal 18 - 37

p-ISSN : $2356-492 x$

e-ISSN : $2549-9270$

\title{
PROGRAM PEMBERDAYAAN EKONOMI MUSTAHIK PADA UMKM DI LEMBAGA ZAKAT CENTER KOTA CIREBON
}

\author{
Wartoyo $^{1}$, Nila Ernila ${ }^{2}$ \\ 1,2IAIN Syekh Nurjati Cirebon \\ 1,2Jl. Perjuangan, Sunyaragi, Kec.Kesambi, Kota Cirebon, Jawa Barat \\ 1 wartoyo10@gmail.com \\ 2 nilaernila800@gmail.com
}

\begin{abstract}
Zakat is not only for consumptive needs but also for productive business development needs so that in time the mustahik can become muzakki. The Zakat Center's efforts to provide venture capital, assistance and guidance to its assisted mustahik that reach c accelerated business development. The purpose of this study was to determine the effect of business capital, mentoring and coaching in an independent economic program towards increasing the income of mustahik micro-businesses both partially and simultaneously. This study uses a quantitative approach with data collection techniques using questionnaires distributed to 88 partners assisted by independent economic programs at the Zakat Center. The results showed that the business capital variable did not affect the increase in mustahik micro-business income, the assistance variable had an effect on the increase in mustahik micro-business income, and the coaching variable had an effect but was not significant on the increase in mustahik micro-business income, and simultaneously influential business capital, mentoring and influential guidance significant increase in mustahik micro business income.
\end{abstract}

Keyword : Mustahiq, micro business, empowerment

\begin{abstract}
Abstrak
Dewasa ini zakat tidak hanya disalurkan untuk kebutuhan konsumtif akan tetapi juga untuk kebutuhan pengembangan usaha produktif agar pada saatnya nanti para mustahik dapat menjadi muzakki. Upaya Zakat Center melakukan pemberian modal usaha, pendampingan dan pembinaan terhadap para mustahik binaannya merupakan upaya untuk menciptakan akselerasi pengembangan usaha. Tujuan penelitian ini adalah untuk mengetahui pengaruh modal usaha, pendampingan dan pembinaan dalam program ekonomi mandiri terhadap peningkatan pendapatan usaha mikro mustahik baik secara parsial maupun simultan. Penelitian ini menggunakan pendekatan kuantitatif dengan teknik pengumpulan data menggunakan angket yang disebar kepada 88 mitra binaan program ekonomi mandiri di Zakat Center. Hasil penelitian menunjukan variabel modal usaha tidak berpengaruh terhadap peningkatan pendapatan usaha mikro mustahik, variabel pendampingan berpengaruh terhadap peningkatan pendapatan usaha mikro mustahik, dan variabel pembinaan berpengaruh namun tidak signifikan terhadap peningkatan pendapatan usaha mikro mustahik, dan secara simultan penyaluran modal usaha, pendampingan dan pembinaan berpengaruh signifikan terhadap peningkatan pendapatan usaha mikro mustahik.
\end{abstract}

Kata Kunci: Mustahiq, usaha mikro, pemberday 


\section{9 | Program Pemberdayaan Ekonomi Mustahik Pada UMKM di Lembaga Zakat Center Kota Cirebon}

\section{PENDAHULUAN}

Zakat adalah ibadah dalam bidang harta yang mempunyai manfaat besar dan mulia, baik yang berkaitan dengan orang yang berzakat (muzaki), penerimanya (mustahik), harta yang dikeluarkan zakatnya maupun bagi masyarakat keseluruhan (Hafidhuddin, 2002). Zakat juga sebagai perwujudan keimanan kepada Allah SWT dan menumbuhkan akhlak mulia dengan rasa kemanusiaan yang tinggi karena zakat merupakan hak mustahik, maka zakat berfungsi untuk menolong, membantu dan membina mereka sehingga mereka dapat memenuhi kebutuhan hidupnya dengan layak, bukan sekedar kebutuhan konsumtif dalam waktu sesaat, akan tetapi memberikan kecukupan dan kesejahteraan kepada mereka, dengan cara menghilangkan atau memperkecil penyebab kehidupan mereka menjadi miskin dan menderita. Dalam Undang-Undang RI Nomor 38 tahun 1999 tentang Pengelolaan Zakat Bab III pasal 6 dan pasal 7 menyatakan bahwa lembaga pengelola zakat di Indonesia terdiri dari dua macam, yaitu Badan Amil Zakat (BAZ) dan Lembaga Amil Zakat (LAZ). Badan Amil Zakat dibentuk oleh pemerintah, sedangkan Lembaga Amil Zakat didirikan oleh masyarakat (Hafidhuddin, 2002).

Lembaga Amil Zakat (LAZ) merupakan lembaga yang berfungsi sebagai lembaga intermediary yang bergerak mengumpulkan dan menyalurkan dana zakat umat. Dalam pendistribusiannya, Lembaga Amil Zakat memiliki dua pola, yakni distribusi konsumtif dan distribusi produktif. (1) Distribusi konsumtif, yaitu pendistribusian zakat yang dibagikan kepada mustahik untuk dimanfaatkan secara langsung, realisasinya terdapat tiga upaya, yakni upaya pemenuhan kebutuhan konsumsi dasar seperti pemenuhan sembako, kemudian upaya pemenuhan kebutuhan yang berkaitan dengan tingkat kesejahteraan sosial dan psikologi dalam bentuk renovasi atau pembangunan tempat-tempat pemukiman, dan nikahan atau sunatan masal dan yang ketiga adalah upaya pemenuhan kebutuhan peningkatan sumber daya manusia agar dapat bersaing hidup di dalam transisi ekonomi dan demokrasi Indonesia seperti peningkatan kualitas pendidikan berupa beasiswa serta pendidikan dan pelatihan untuk peningkatan keterampilan nonformal (luar sekolah). (2) Distribusi produktif adalah distribusi zakat yang bertujuan untuk mengoptimalkan sistem zakat dalam perekonomian (Mufraini, 2008). Pola distribusi produktif yang dikembangkan pada umumnya mengambil skema qardhul hasan, yakni satu bentuk peminjaman yang menetapkan tidak adanya tingkat pengembalian tertentu dari pokok pinjaman.

Lembaga-lembaga zakat semakin banyak didirikan dan program-program yang dilaksanakanpun semakin meningkat, namun persoalan zakat adalah sesuatu yang tidak pernah habis dibicarakan, wacana tersebut terus bergulir mengikuti peradaban Islam. Di Indonesia, persoalan zakat yang muncul saat ini adalah peran zakat sebagai salah satu rukun Islam yang harus ditunaikan oleh umat Islam yang mampu (muzakki) hanya menjadi 
kesadaran personal. Kemudian persoalan kedua adalah meningkatnya kesadaran umat Islam dalam membayar zakat tidak disertai dengan pengumpulan dan penyaluran yang terencana secara komprehensif, sehingga bagaimana zakat dapat memiliki peran yang sangat penting dalam menentukan ekonomi umat agar terkelola dengan baik dan professional-produktif karena pengelolaan yang tidak baik dan profesional menjadikan zakat tidak produktif dalam mengembangkan ekonomi umat (Labib, 2017). Permasalahan ini sejalan dengan angka kemiskinan yang semakin meningkat, walaupun penghimpunan dan penyaluran zakat sudah banyak dilakukan, namun kemiskinan semakin meningkat, hal ini dibuktikan pada tabel berikut:

\begin{tabular}{|c|c|c|c|c|c|c|c|c|c|c|}
\hline \multicolumn{11}{|c|}{ Tabel 1.1} \\
\hline \multicolumn{11}{|c|}{ Angka Kemiskinan } \\
\hline \multirow{3}{*}{ Profinsi } & \multicolumn{10}{|c|}{ Perkotaan } \\
\hline & \multicolumn{2}{|c|}{2013} & & 014 & & 2015 & & 016 & \multicolumn{2}{|c|}{2017} \\
\hline & Semester 1 & Semester & Semester 1 & 1 Semester 2 & Semester 1 & 1 Semester 2 & Semester 1 & 1 Semester 2 & Semester 1 & 1 Semester 2 \\
\hline Jawa Barat & 258.538 & 281.189 & 288.742 & 294.700 & 307.487 & 318.297 & 325.017 & 332.145 & 345.151 & \begin{tabular}{|l|l|}
1 & -
\end{tabular} \\
\hline
\end{tabular}

Sumber: Badan Pusat Statistik Kota Cirebon

Dari tabel 1 tersebut dapat dilihat bahwa dari tahun 2013 semester 1 sampai tahun 2017 semester 1 angka kemiskinan semakin meningkat setiap semesternya, hal ini menandakan bahwa zakat yang disalurkan belum sepenuhnya meningkatkan perekonomian umat Islam. Persoalan tentang zakat memang tidak pernah habis dibicarakan, karena zakat merupakan salah satu sumber dana untuk mengatasi masalah perekonomian yang dialami semua umat, namun dibalik persoalan itu umat Islam tidak hanya berdiam tetapi mereka mencoba untuk mengatasinya dengan mendirikan beberapa Lembaga Amil Zakat untuk mengatasi persoalan ekonomi sehingga masyarakat yang masih menjadi mustahik dapat meningkatkan taraf hidupnya menjadi seorang muzaki.

Pengentasan keterpurukan hidup kaum dhuafa ini menjadi ruh yang menjiwai Zakat Center sejak awal dirintisnya, meningkatkan nilai guna ZISWA melalui program peningkatan kualitas sumber daya manusia dan pemberdayaan ekonomi produktif yang menjadi prioritas prestasi yang ditekankan oleh lembaga ini disamping fungsi sosialnya, dan hal inilah yang melatar belakangi penulis untuk melakukan penelitian di Zakat Center Thoriqotul Jannah Cirebon. Zakat produktif merupakan zakat yang diberikan kepada mustahik dalam bentuk modal kerja, zakat produktif ini ditujukan kepada para mustahik yang memiliki usaha kecil dengan tujuan agar usaha tersebut dapat berkembang sehingga mereka mampu memenuhi kebutuhan hidupnya. Akan tetapi, yang perlu diperhatikan disini adalah bahwa dalam pengelolaan zakat produktif tersebut diperlukan adanya pendampingan dan pelatihan sehingga tujuan zakat produktif tersebut dapat tercapai. Tujuan lain dari zakat produktif adalah mustahik yang berhasil mengelola dana dari muzaki nantinya bisa berubah menjadi 


\section{1 | Program Pemberdayaan Ekonomi Mustahik Pada UMKM di Lembaga Zakat Center Kota Cirebon}

muzaki sehingga dana tersebut dapat terus bergulir dan meningkatkan perekonomian secara luas (Nasrullah, 2006).

Zakat Center salah satu lembaga yang ingin mengatasi persoalan zakat di Indonesia saat ini, terbukti dengan pengadaan program-program yang bertujuan untuk meningkatkan taraf hidup mustahiknya, keseriusan zakat center dalam melaksanakan programnya terbukti dengan sejumlah dana yang dikelurkan dari penghimpunan dana yang dilakukan oleh Zakat Center untuk keberlangsungan dan perkembangan program-program tersebut, dengan rincian sebagai berikut:

Tabel 1.2

Ringkasan Laporan keuangan Zakat Center Thoriqotul Jannah Cirebon

\begin{tabular}{||c|c|c|c|c|c|}
\hline \hline \multicolumn{1}{|c|}{ Keterangan } & 2012 & 2013 & 2014 & 2015 & 2016 \\
\hline Penghimpunan Dana ZISWA & $\operatorname{Rp~1.616.295.176,00~}$ & $\operatorname{Rp} 2.342 .602 .391,00$ & $\mathrm{Rp} 2.057 .122 .250$ & $\mathrm{Rp} \mathrm{2.254.284.173}$ & $\mathrm{Rp} 2.717 .552 .726$ \\
\hline Dana Penyaluran Program & $\mathrm{Rp} \mathrm{1.054.323.700,00}$ & $\mathrm{Rp} \mathrm{1.817.929.150,00}$ & $\mathrm{Rp} \mathrm{1.571.865.425}$ & $\mathrm{Rp} \mathrm{1.654.854.300}$ & $\mathrm{Rp} 2.206 .500 .753$ \\
\hline
\end{tabular}

Sumber: Laporan Arus Kas Zakat Center Thoriqotul Jannah Cirebon

Lembaga Zakat Center ini merupakan salah satu lembaga yang mempunyai komitmen terhadap pengembangan peningkatan kualitas sumber daya manusia dan pemberdayaan ekonomi produktif. Dapat dilihat pada tabel, bahwa tahun 2012 saja Zakat Center sudah menyalurkan 65\% dari penghimpunan dana untuk penyaluran program-programnya. Zakat Center dalam rangka meningkatkan taraf hidup mustahik, mengadakan program zakat produktif, yaitu program ekonomi mandiri yang terdiri dari tiga pelaksanaan yaitu bantuan modal usaha mandiri, pendampingan dan pembinaan, namun belum bisa dipastikan ketiganya ini akan saling bersinergi dalam memberdayakan ekonomi mustahik, karena dari beberapa penelitian terdahulu terdapat perbedaan hasil penelitian.

Seperti penelitian Fathurrohman (Fathurrohman, 2016) yang menyimpulkan bahwa modal usaha berpengaruh positif tetapi tidak signifikan terhadap kesejahteraan mustahik, Siti Halida Utami (Utami \& Lubis, 2013) pada penelitiannya menyatakan bahwa dalam pelaksanaan zakat produktif, masih adanya penyalahgunaan bantuan modal usaha yang diberikan dan beberapa mustahik masih menggunakan bantuan tersebut sebagai pemenuhan kebutuhan konsumtif. Dari beberapa penelitian sebelumnya terdapat juga penelitian yang menghasilkan penelitian berbeda pendapat dengan penelitian tersebut, salah satunya adalah penelitian yang dilakukan oleh Haikal Luthfi Fathullah (Fathullah, 2015) yang menghasilkan bahwa secara simultan dan parsial bantuan modal usaha, pelatihan usaha, pendampingan usaha, dan lama usaha berpengaruh signifikan terhadap pendapatan mustahik.

Penelitian ini ditujukan untuk mengukur sejauh mana pengaruh penyaluran modal usaha, pendampingan dan pembinaan program ekonomi mandiri dalam meningkatkan pendapatan usaha mikro mustahik, karena modal usaha, pembinaan dan pendampingan sangat penting sekali dalam pemberdayaan ekonomi produktif, ketika bantuan modal usaha 
mandiri diserahkan kepada mustahik kita tidak pernah tahu apakah modal tersebut benarbenar digunakan untuk usaha atau untuk kebutuhan konsumtif, serta pemberian bantuan modal usaha mandiri tidak akan sepenuhnya bisa membantu mitra binaan dalam menjalankan usaha, karena yang menjalankan usaha adalah mitra binaan itu sendiri, sehingga mitra binaan tersebut perlu dibekali dengan pembinaan dan pendampingan agar dapat menjalankan usahanya dengan ilmu yang didapat dari pembinaan dan pendampingan yang rutin diadakan oleh Zakat Center, hal ini berguna juga agar lembaga bisa mengetahui bahwa bantuan yang disalurkannya sudah tepat guna.

Pemberian modal usaha yang diberikan maksimal adalah $\mathrm{Rp} 500.000,-$ dan untuk selanjutnya Zakat Center memberikan bantuan apabila mitra binaan memerlukan perlengkapan usaha lain, seperti spanduk atau brosur. Dalam pelaksanaan program ekonomi mandiri, Zakat Center juga mengadakan pembinaan yang berupa forum kajian untuk pembinaan ibu-ibu dan bapak-bapak pedagang kecil yang sudah menjadi mitra binaan, didalam kajian tersebut berisi materi-materi yang disampaikan seputar ekonomi, agama dan pengetahuan lainnya, pembinaan ini dilakukan setiap satu bulan sekali dan kadang-kadang ada cek kesehatan gratis untuk mitra binaan dan amil zakat, sedangkan pendampingan didalam Zakat Center bertujuan untuk memantau usaha dari mitra binaan, apakah lancar atau tidak, ada kemajuan atau tidak serta memantau ibadahnya, kesejahteraan keluarganya dan juga untuk berkonsultasi mengenai kendala-kendala yang terjadi. Tentunya menarik untuk dilakukan penelitian lebih jauh terhadap dampak dari program penyaluran dana zakat di lembaga Zakat Center ini, sehingga tujuan dari penelitian ini untuk melihat pengaruh pemberian modal usaha, pendampingan dan pembianaan program ekonomi mandiri terhadap peningkatan pendapatan UMKM binaan lembaga Zakat Center baik secara parsial maupun secara simultan.

\section{TINJAUAN TEORITIK}

\subsection{Zakat Produktif}

Zakat produktif adalah pengelolaan dan penyaluran dana zakat yang bersifat produktif, yang mempunyai efek jangka panjang bagi para penerima zakat. Penyaluran dana zakat produktif ini dilakukan dalam rangka mewujudkan salah satu tujuan disyariatkannya zakat, yaitu mengentaskan kemiskinan umat secara bertahap dan berkesinambungan (Musaddad, 2006). Zakat secara produktif ini bukan tanpa dasar, zakat ini pernah terjadi di zaman Rasulullah dikemukakan dalam sebuah hadits riwayat Imam Muslim dari Salim Bin Abdillah Bin Umar dari ayahnya, bahwa Rasulullah telah memberikan kepadanya zakat lalu menyuruhnya untuk dikembangkan atau disedekahkan lagi. Dalam kaitan dengan penyaluran zakat yang bersifat produktif, ada pendapat menarik yang dikemukakan oleh Syekh Yusuf 


\section{3 | Program Pemberdayaan Ekonomi Mustahik Pada UMKM di Lembaga Zakat Center Kota Cirebon}

Qardhawi, dalam bukunya yang fenomenal, yaitu Fiqh Zakat, bahwa pemerintah Islam diperbolehkan membangun pabrik-pabrik atau perusahaan-perusahaan dari uang zakat untuk kemudian kepemilikan dan keuntungannya digunakan bagi kepentingan fakir miskin, sehingga akan terpenuhi kebutuhan hidup mereka sepanjang masa dan untuk saat ini peranan pemerintah dalam pengelolaan zakat digantikan oleh Badan Amil Zakat atau Lembaga Amil Zakat (amirah, 2012). Hukum zakat prouktif adalah boleh, bahkan sangat dianjurkan. Karenanya, konsep distribusi produktif yang dikedepankan oleh sejumlah lembaga penghimpun dan penyalur zakat, biasanya dipadupadankan dengan dana terkumpul lainya yaitu sedekah dan infak (Mufraini, 2006).

Selama ini dalam prakteknya, zakat yang disalurkan ke masyarakat lebih didominasi oleh zakat konsumtif sehingga ketika zakat tersebut selesai didistribusikan maka manfaat yang diterima oleh mustahiq hanya dapat digunakan dalam kurun waktu yang singkat. Tujuan zakat tidak sekedar menyantuni orang miskin secara konsumtif, tetapi mempunyai tujuan yang lebih permanen yaitu mengentaskan kemiskinan (Qadir, 2001). Pengentasan kemiskinan melalui zakat juga memiliki arti mengurangi jumlah mustahik dan menghasilkan para muzakki yang baru. Oleh karena itu pendistribusian zakat konsumtif harus ditinjau ulang kembali dan digantikan dengan pendistribusian zakat produktif.

Zakat produktif adalah pemberian zakat yang dapat membuat para penerimanya menghasilkan sesuatu secara terus menerus, dengan harta zakat yang telah diterimanya (Asnaini, 2008). Pengembangan zakat bersifat produktif dengan cara dijadikannya dana zakat sebagai modal usaha, untuk pemberdayaan ekonomi penerimanya, dan supaya fakir miskin dapat menjalankan atau membiayai kehidupannya secara konsisten. Dengan dana zakat tersebut fakir miskin akan mendapatkan penghasilan tetap, meningkatkan dan mengembangkan usaha mikronya, serta mereka dapat menyisihkan penghasilannya untuk menabung dan berinfak (Sartika, 2008).

Kekurangan modal bukan merupakan satu-satunya kelemahan golongan miskin dalam membangun usahanya, tetapi juga kemauan untuk maju, kesiapan mental, dan kesiapan manajemen usaha. Pada tahap awal pendistribusian zakat terutama zakat produktif, pihak amil zakat memberikan pemberdayaan dalam bentuk pembinaan yaitu mendidik dan mengarahkan mustahik agar memiliki keinginan untuk maju dan berkembang, kemudian mendampingi mustahik dalam menjalankan usahanya sehingga kegiatan usahanya tersebut dapat berjalan dengan baik dan agar para mustahik semakin meningkatkan kualitas keimanan dan keislamannya (Hafidhuddin, 2002). 


\subsection{Konsep Pemberdayaan Zakat Produktif}

Konsep pemberdayaan umat berkaitan dengan pendayagunaan dana zakat, yakni bentuk pemanfaatan sumber daya (dana zakat) secara maksimum sehingga berdayaguna untuk mencapai kemaslahatan bagi umat, sehingga dengan pemberdayaan ini diharapkan dapat membentuk sikap dan perilaku hidup individu dan kelompok menuju kemandirian. Dengan demikian pemberdayaan adalah upaya memperkuat posisi sosial dan ekonomi dengan tujuan mencapai penguatan kemampuan umat melalui dana bantuan yang pada umumnya berupa kredit untuk usaha produktif sehingga mustahik sanggup meningkatkan pendapatannya dan juga membayar kewajibannya (zakat) dari hasil usaha atas kredit yang dipinjamnya (Khasanah, 2010).

Pendayagunaan berasal dari kata daya-guna yang berarti kemampuan mendatangkan hasil atau manfaat (Hasan, 2006), adapun pengertian pendayagunaan menurut Undang-undang No. 38 tahun 1999 pasal 16 ayat (1) dan (2) tentang pengelolaan zakat, secara eksplisit dinyatakan bahwa pendayagunaan zakat adalah untuk memenuhi kebutuhan hidup para mustahik sesuai dengan ketentuan agama (delapan asnaf) dan dapat dimanfaatkan untuk usaha produktif. Spesifiknya, Keputusan Menteri Agama Nomor 373 tahun 2003 pasal 28 ayat (2) dijelaskan bahwa pendayagunaan zakat untuk usaha produktif dilakukan apabila zakat sudah dapat memenuhi kebutuhan hidup para mustahiq dan ternyata masih dapat kelebihan, dengan demikian secara garis besar dana zakat dapat didistribusikan pada dua jenis kegiatan, yaitu kegiatan yang bersifat konsumtif dan produktif.

Istilah pendayagunaan dalam konteks ini mengandung makna pemberian zakat kepada para mustahik secara produktif dengan tujuan agar zakat mendatangkan hasil dan manfaat bagi yang memproduktifkan, bentuk-bentuk penyaluran dana zakat antara lain:

a. Bentuk sesaat, dalam hal ini bahwa zakat hanya diberikan kepada seseorang satu kali atau sesaat saja, tanpa disertai target terjadinya kemandirian ekonomi dalam diri mustahiq.

b. Bentuk pemberdayaan, merupakan penyaluran zakat yang disertai target merubah keadaan penerima dari kondisi kategori mustahik menjadi kategori muzakki.

Sifat dana bantuan pemberdayaan zakat produktif terdiri dari tiga penyaluran, yaitu:

a. Hibah, zakat pada dasarnya diberikan dalam bentuk hibah artinya tidak ada ikatan antara pengelola dengan mustahik setelah penyerahan zakat. 


\section{5 | Program Pemberdayaan Ekonomi Mustahik Pada UMKM di Lembaga Zakat Center Kota Cirebon}

b. Dana bergulir, Zakat dapat diberikan dalam bentuk pinjaman dari pengelola kepada mustahik dengan akad qardhul hasan, artinya tidak boleh ada kelebihan yang harus diberikan oleh mustahik kepada pengelola ketika pengembalian pinjaman tersebut.

c. Pembiayaan, penyaluran zakat oleh pengelola kepada mustahiq tidak boleh dilakukan berupa pembiayaan, artinya tidak boleh ada ikatan seperti shahibul maal dengan mudharib dalam penyaluran zakat (Widodo, 2001).

Menurut Muhammad Daud Ali pendayagunaan dana zakat dapat dikategorikan sebagai berikut:

a. Pendayagunaan yang konsumtif dan tradisional sifatnya dalam kategori ini penyaluran diberikan kepada orang yang berhak menerimanya untuk dimanfaatkan langsung oleh yang bersangkutan seperti: zakat fitrah yang diberikan pada fakir miskin untuk memenuhi kebutuhan sehari-hari atau zakat harta yang diberikan kepada korban bencana alam.

b. Pendayagunaan yang konsumtif kreatif, maksudnya penyaluran dalam bentuk alat-alat sekolah atau beasiswa, dll.

c. Pendayagunaan produktif tradisional, maksudnya penyaluran dalam bentuk barang-barang produktif, misalnya kambing, sapi, alat-alat pertukaran, dan lain sebagainya. Tujuannya adalah untuk menciptakan suatu usaha atau memberikan lapangan kerja bagi fakir miskin.

d. Pendayagunaan produktif kreatif, pendayagunaan ini mewujudkan dalam bentuk modal yang dapat dipergunakan baik untuk membangun sebuah proyek sosial maupun untuk membantu atau menambah modal seorang pedagang atau pengusaha kecil (Mufraini, 2006).

Program pemberdayaan ekonomi masyarakat melalui pendayagunaan dana zakat yang dilakukan oleh Lembaga Amil Zakat (LAZ) dapat menjawab dan memberikan solusi atas berbagai permasalahan yang dihadapi oleh masyarakat. Dalam hal ini Lembaga Amil Zakat (LAZ) melakukan pemberdayaan ekonomi melalui beberapa program sebagai berikut:

a. pemberdayaan ekonomi melalui usaha kecil dengan program pendampingan dan pembinaan

b. pemberdayaan ekonomi umat melalui program pelatihan kewirausahaan dan penyaluran bantuan dana usaha bagi pedagang dan pengusaha kecil (Fakhruddin, 2008).

Badan atau Lembaga Amil Zakat menetapkan skala prioritas yang lebih berat pada bantuan ekonomi produktif dalam bentuk permodalan dan pembinaan usaha, karena dengan program ini akan bisa mentransfer mustahik menjadi 
muzaki. Kebijakan program pemberdayaan yang diterapkan itu memang tidak salah, mengingat semangat yang ditanamkan oleh Islam kepada umatnya melalui ajaran tentang zakat, yaitu semangat untuk berusaha dan memperbaiki kehidupan menuju taraf hidup yang lebih baik atau dengan kata lain mengubah ketergantungan menjadi kemandirian, mengubah hidup kekurangan menjadi berkecukupan dan mengubah mustahik menjadi muzakki melalui multi manfaat zakat (Khasanah, 2010).

\subsection{Manajemen Pengelolaan Zakat Produktif}

Manajemen berasal dari bahasa Inggris management, dengan akar kata kerja manage yang diartikan secara umum sebagai mengurusi. Manajemen adalah ilmu dan seni yang sangat penting yang telah merasuki dan mempengaruhi hampir seluruh aspek kehidupan. Dengan manajemen manusia mampu mempraktikan cara-cara efektif dan efisien dalam pelaksanaan pekerjaan. Begitu pula dalam hal pengurusan zakat, manajemen dapat dimanfaatkan untuk merencanakan, menghimpun, mendayagunakan dan mengembangkan perolehan dana zakat secara efektif dan efisien (Khasanah, 2010).

Manajemen zakat sendiri adalah proses kegiatan melalui kerja sama orang lain dalam rangka pendayagunaan zakat sebagai pilar kekuatan ekonomi dan sarana peningkatan kesejahteraan dan pencerdasan umat Islam (Ridwan, 2005). Dengan demikian tujuan utama menajemen zakat adalah memperoleh suatu teknik yang baik dan tepat agar mempermudah dan mempercepat proses pencapaian tujuan secara efektif dan efisien. Pengelolaan berasal dari kata kelola yang berarti mengendalikan atau menyelenggarakan, sedangkan kata pengelolaan berarti proses melakukan kegiatan tertentu dengan menggerakkan tenaga orang lain, atau dapat juga diartikan proses pemberian pengawasan pada semua hal yang terlibat dalam pelaksanaan kebijaksanaan dan pencapaian tujuan (Departemen Pendidikan Nasional, 2007).

Pengelolaan yang kaitannya dengan zakat meliputi sosialisasi zakat, pengumpulan zakat, pendistribusian, pendayagunaan dan pengawasan zakat. Dengan demikian pengelolaan zakat adalah proses dan pengorganisasian sosialisasi, pengumpulan, pendistribusian, pendayagunaan, dan pengawasan dalam pelaksanaan zakat (Hasan, 2006). Aktivitas pengelolaan zakat didasarkan pada prinsip-prinsip manajemen yang akan membantu memudahkan organisasi mencapai tujuan dengan baik dan sempurna, pengelolaan zakat dalam kaitannya dengan manajemen memiliki makna menata dan mengembangkan semua aktivitas yang berkaitan dengan zakat, baik penghimpunan maupun penyaluran. Untuk mengoptimalkan manajemen pengelolaan zakat produktif, muncul konsepsi kontemporer tentang permasalahan 


\section{7 | Program Pemberdayaan Ekonomi Mustahik Pada UMKM di Lembaga Zakat Center Kota Cirebon}

zakat yang telah jauh melampui pendapat-pendapat hukum klasik, terutama menyangkut tiga hal pokok, yaitu:

\section{a. Pengembangan Obyek Zakat}

Obyek zakat tidak selalu harus sesuai dengan ketentuan-ketentuan yang telah diterapkan dalam Al-Qur"an dan Al-Hadits (Mas'ud, 2005), karena perlu adanya terobosan baru dalam menentukan obyek zakat, perluasan obyek zakat berdasarkan lingkungan dan kedinamisan kehidupan maka akan mengsilkan objek zakat yang sangat luas, misalnya harta rikaz (emas dan perak ) dapat dikembangkan menjadi batu mulia, permata, berlian dan sebagainya. Profesi misalnya, saat ini banyak sekali profesi yang menghasilkan uang dalam jumlah besar, misalnya para pejabat tinggi negara, pengusaha, dokter, pengacara dan sebagainya.

\section{b. Kelembagaan Zakat}

Dalam rangka mengoptimalkan pendapatan dana zakat perlu pengelolaan yang berkualitas, untuk itu perlu adanya badan pengelola zakat, untuk membentuk sebuah badan pengelola zakat yang berkualitas paling tidak ada tiga hal yang harus dipenuhi, yakni amanah, fatonah, dan transparan, transparan sebagai wujud keterbukaan atas dana zakat yang dikelola, dengan cara memberikan laporan secara langsung kepada masyarakat dengan memanfaatkan teknologi yang dapat diakses oleh publik secara luas (Mas"e ud, 2005).

Ditegaskan dalam pasal 27 UU No 23 Tahun 2011 tentang pengelolaan zakat, bahwa (Zuhri, 2012):

a. Zakat dapat didayagunakan untuk usaha produktif dalam rangka penanganan fakir miskin dan peningkatan kualitas umat.

b. Pendayagunaan zakat untuk usaha produktif sebagaimana dimaksud pada ayat

(1) dilakukan apabila kebutuhan dasar mustahik telah terpenuhi.

Pengelolaan zakat yang baik harus dikelola oleh Badan atau Lembaga Amil Zakat yang baik pula, jika kinerja organisasi yang baik ingin dicapai, maka hal itu harus dimulai dari perencanaan yang baik, begitupula jika ingin mencapai kinerja pengelolaan dan pendayagunaan dana zakat yang optimum, setiap badan atau lembaga amil zakat harus sudah memiliki rencana kerja sebelum mereka melangkah. Rencana kerja lembaga amil zakat meliputi pendataan mustahik dan muzakki, proyeksi perolehan zakat, rencana publikasi iklan, dan rencana program pemberdayaan. Rencana kerja tersebut didasarkan pada kebutuhan dari seluruh fungsi dalam struktur badan pelaksana, kondisi lapangan dan kemampuan dukungan sumberdaya yang tersedia. Didalam badan pelaksana terdapat beberapa fungsi, sekurangnya meliputi Bagian Penghimpunan Dana Zakat, Bagian keuangan, dan Bagian Pendayagunaan. 


\section{c. Sistem dan manajemen pengelolaan zakat}

Pengelolaan zakat yang baik harus dilengkapi dengan sistem dan prosedur penghimpunan dan penyaluran yang jelas dan legible, salah satunya adalah memiliki sistem administrasi yang baik sebagaimana tercermin pada alat-alat kerja berupa berbagai macam formulir dan catatan untuk seluruh transaksi kegiatan, begitu juga setiap transaksi yang berkaitan dengan pengeluaran dan pemasukan dana tercatat dalam laporan akuntansi yang jelas dan rapi.

Pengelolaan zakat yang baik dalam hal penyaluran dana zakat dilaksanakan dengan menetapkan alokasi dan bidang penyaluran melalui mekanisme yang tersedia, sehingga alokasi dana tersebut tidak hanya disalurkan dalam bentuk uang tunai untuk kebutuhan konsumtif justru disalurkan dalam bentuk berbagai program zakat produktif. Diharapkan bahwa pola penyaluran seperti ini tidak melestarikan mustahik sebagai mustahik abadi melainkan dapat mentransformasikan mereka dari mustahik menjadi muzakki.

Usaha mikro adalah industri kerajinan rumah tangga, yaitu perusahaan/ usaha industri pengolahan yang mempunyai pekerja 1- 4 orang, sedangkan industri kecil mempekerjakan 5 - 19 orang (BPS, 2010). Sementara menurut Departemen Perindustrian dan Perdagangan mendefinisikan industri atau perdagangan mikro adalah industri-perdagangan yang mempunyai tenaga kerja 1- 4 orang.

Keberadaan usaha mikro hendaknya dapat memberikan kontribusi yang cukup baik terhadap masalah kemiskinan dan pengangguran. Pembangunan dan pertumbuhan usaha mikro merupakan salah satu penggerak yang krusial bagi pembangunan dan pertumbuhan ekonomi disetiap negara (Sintha Dwi Wulansari \& Achma Hendra Setiawan, 2014).Usaha Mikro dapat mencakup paling sedikit dua aspek yaitu penyerapan tenaga kerja dan pengelompokkan perushaaan dilihat dari jumlah tenaga kerja yang dapat diserap. Posisi Usaha Mikro yang sangat penting, ternyata masih banyak mengalami permasalahan. Menurut Tulus (2002) masalah mendasar yang dihadapi oleh usaha mikro meliputi: (1) Keterbatasan Sumber Daya Manusia (SDM); (2) Kesulitan Pemasaran; (3) Keterbatasan Finansial; (4) Masalah Bahan Baku; (5) Keterbatasan Teknologi. Untuk itu tepat rasanya bila programprogram penyaluran zakat produktif dari lembaga-lembaga zakat lebih diarahkan untuk melakukan pemberdayaan ekonomi para pengusan kecil sehingga dapat mengangkat tingkat ekonomi dan kehidupan mereka ke depan. 

Center Kota Cirebon

\section{METODE PENELITIAN}

\subsection{Tipe Penelitian}

Penelitian ini menggunakan metode kuantitatif yaitu penelitian dengan data penelitian berupa angka-angka dan analisis menggunakan statistik (Sugiyono, 2017). dan berjenis penelitian lapangan (field research) dengan analisis data menggunakan teknik analisis linier berganda dengan program SPSS. Adapun sebelum dilakukan analisis data dilakukan proses validitas dan reabilitas data, uji prasyarat berupa uji normalitas, heteroskedastisitas, multikolieritas dan autokorelasi. Dan semua data yang terkumpul telah dipastikan lolos semua uji tersebut. Adapun sumber data primer yang didapatkan melalui penyebaran kuisioner terhadap para responden yang menjadi sample dari total populasi yang ada sebanyak 45 orang. sedeangkan sumber data sekunder berupa dokumentasi dan bahan bacaan lain yang menunjang bagi kelengkapan data dalam penelitian ini.

\subsection{Hipotesis Penelitian}

Zakat produktif dalam bentuk modal usaha akan membantu mustahik dalam meningkatkan pendapatan usaha mikronya, melalui modal tersebut mustahik dapat menggunakannya untuk pengembangan usaha, pernyataan ini didukung oleh penelitian yang dilakukan Hidayat Aji Pambudi (Pambudi, 2012) yang menyimpulkan bahwa zakat produktif berpengaruh secara signifikan terhadap penghasilan mustahik. Hal ini menandakan bahwa semakin tinggi nilai zakat produktif yang diterima mustahik semakin tinggi pula tingkat penghasilannya, sehingga dapat membentuk hipotesis berikut:

H1 : Modal Usaha Program Ekonomi Mandiri berpengaruh signifikan terhadap peningkatan pendapatan usaha mikro mustahik.

H2 : Pendampingan Program Ekonomi Mandiri berpengaruh signifikan terhadap peningkatan pendapatan usaha mikro mustahik.

H3 : Pembinaan Program Ekonomi Mandiri berpengaruh secara signifikan terhadap peningkatan pendapatan usaha mikro mustahik.

H4 : Modal usaha, pendampingan dan pembinaan berpengaruh secara simultan signifikan terhadap peningkatan pendapatan usaha mikro mustahik.

\subsection{Penelitian Pendukung}

Pertama, penelitian yang dilakukan oleh Hidayat Aji Pambudi (2012) yang menyatakan bahwa pengawasan dan pendampingan berpengaruh secara signifikan terhadap penghasilan mustahik. 
Kedua, penelitian yang dilakukan oleh Haikal Luthfi Fathullah (2016) yang menghasilkan bahwa pendampingan usaha berpengaruh signifikan terhadap pendapatan mustahik.

Ketiga, penelitian yang dilakukan oleh Nur Fathurrohman (2016) yang menyimpulkan bahwa pendampingan berpengaruh positif dan signifikan terhadap kesejahteraan mustahik.

Keempat, penelitian yang dilakukan oleh Mohamad Soleh Nurzaman dan kawan-kawan (2017) yang menyatakan bahwa pembinaan sangat penting untuk menjamin keberlanjutan program zakat produktif agar usaha mustahik tumbuh dan berkembang secara mandiri.

Kelima, Susi Hendriani dan Soni Nulhaqim (2008) yang menyatakan bahwa pembinaan mempunyai pengaruh yang signifikan dalam menumbuhkan jiwa wirausaha mitra binaan pada PT. (Persero) Pelabuhan Indonesia I Cabang Dumai.

Keenam, penelitian yang dilakukan oleh Nur Fathurrohman (2016) yang menyimpulkan bahwa pelatihan, modal usaha dan pendampingan secara bersamasama berpengaruh positif dan signifikan terhadap kesejahteraan mustahik.

Ketujuh, penelitian yang dilakukan oleh Haikal Luthfi Fathullah yang menghasilkan bahwa secara simultan bantuan modal usaha, pelatihan usaha, pendampingan usaha, dan lama usaha berpengaruh signifikan terhadap pendapatan mustahik.

\subsection{Kerangka Pikir}

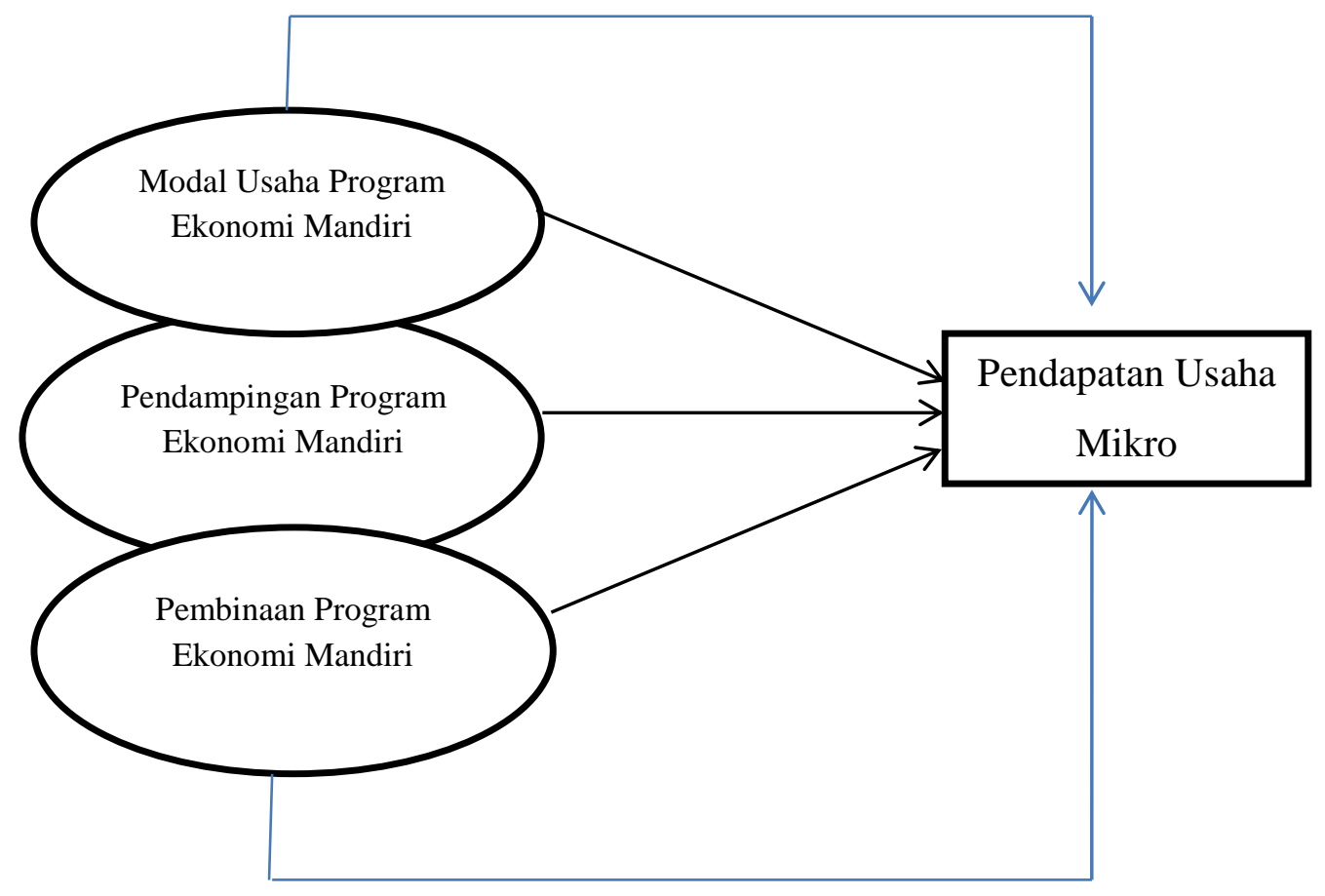

Gambar 3.4 Kerangka Pikir 

Center Kota Cirebon

\section{HASIL DAN PEMBAHASAN}

\subsection{Analisis Regresi Linier Berganda}

Analisis regresi linier berganda digunakan untuk mengetahui bagaimana keadaan variabel apabila nilai variabel mengalami kenaikan atau penurunan dan untuk mengetahui arah hubungan antara variabel dependen, apakah masing-masing variabel independen berhubungan positif atau negatif. Setelah mendapatkan hasil koefisien regresi dengan diolah menggunakan SPSS 20 didapat hasil sebagai berikut:

\section{Tabel 4.1}

Koefisien Regresi Linier Berganda

\begin{tabular}{cc}
\hline Variabel & $\begin{array}{c}\text { Unstandardized } \\
\text { Coefficients }\end{array}$ \\
\hline Constant & 954,779 \\
Modal & 0,054 \\
Pendampingan & 0,304 \\
Pembinaan & 0,164 \\
\hline
\end{tabular}

Sumber: Data primer yang diolah, 2018.

Berdasarkan tabel di atas diperoleh persamaan regresi yang terbentuk adalah:

$$
\begin{gathered}
Y=a+b_{1} X_{1}+b_{2} X_{2}+b_{3} X_{3}+e \\
Y=954,779+0,054 X_{1}+0,304 X_{2}+0,164 X_{3}+e
\end{gathered}
$$

Dari persamaan di atas diperoleh koefisien regresi bernilai positif dari pengaruh modal usaha $\left(\mathrm{X}_{1}\right)$, pendampingan $\left(\mathrm{X}_{2}\right)$ dan pembinaan $\left(\mathrm{X}_{3}\right)$ terhadap pendapatan usaha mikro (Y). Hal ini berarti bahwa:

a. Konstanta sebesar 954,779 dapat diartikan jika modal usaha $\left(\mathrm{X}_{1}\right)$, pendampingan $\left(\mathrm{X}_{2}\right)$ dan pembinaan $\left(\mathrm{X}_{3}\right)$ nilainya konstan atau o, maka pendapatan usaha mikro (Y) mengalami peningkatan sebesar 954,779.

b. Koefisien regresi variabel modal usaha $\left(\mathrm{X}_{1}\right)$ sebesar 0,054 artinya jika nilai modal usaha $\left(\mathrm{X}_{1}\right)$ meningkat sebesar satu satuan, variabel pendampingan $\left(\mathrm{X}_{2}\right)$ dan pembinaan $\left(\mathrm{X}_{3}\right)$ nilainya konstan atau o, maka nilai pendapatan usaha mikro (Y) akan mengalami peningkatan sebesar 0,054.

c. Koefisien regresi variabel pendampingan $\left(\mathrm{X}_{2}\right)$ sebesar 0,304 artinya jika nilai pendampingan $\left(\mathrm{X}_{2}\right)$ meningkat sebesar satu satuan, modal usaha $\left(\mathrm{X}_{1}\right)$ dan pembinaan $\left(\mathrm{X}_{3}\right)$ nilainya konstan atau o, maka nilai pendapatan usaha mikro (Y) akan mengalami peningkatan sebesar 0,304.

d. Koefisien regresi variabel pembinaan $\left(\mathrm{X}_{3}\right)$ sebesar 0,164 artinya jika nilai pembinaan $\left(\mathrm{X}_{3}\right)$ meningkat sebesar satu satuan, modal usaha $\left(\mathrm{X}_{1}\right)$ dan pendampingan $\left(\mathrm{X}_{2}\right)$ nilainya konstan atau o, maka nilai pendapatan usaha mikro (Y) akan mengalami peningkatan sebesar 0,164. 


\subsection{Uji Koefisien Determinasi}

Analisis determinasi digunakan untuk mengetahui prosentase sumbangan pengaruh variabel independen secara bersama-sama terhadap variabel dependen. Untuk melihat pengaruh variabel modal usaha, pendampingan dan pembinaan terhadap pendapatan secara signifikan dan simultan kita akan melihat hasil perhitungan dalam table berikut:

\section{Tabel 4.2 \\ Koefisien Determinasi}

\begin{tabular}{cc}
\hline Adjust R2 & \% pengaruh \\
\hline \hline 0,239 & $23,9 \%$ \\
\hline
\end{tabular}

Sumber: Data primer yang diolah, 2018.

Berdasarkan tabel di atas, diperoleh angka Adjusted $R$ Square sebesar 0,239 atau $23,9 \%$. Hal ini menunjukkan bahwa prosentase sumbangan pengaruh variabel independen (modal usaha, pendampingan dan pembinaan) terhadap variabel dependen (pendapatan) sebesar 23,9\% atau variasi variabel independen yang digunakan dalam model (modal usaha, pendampingan dan pembinaan) mampu menjelaskan sebesar 23,9\% variasi variabel dependen (pendapatan) sedangkan sisanya sebesar 76,1\% dipengaruhi atau dijelaskan oleh variabel lain yang tidak dimasukan dalam model penelitian ini.

\subsection{Pengujian Secara Parsial (Uji t)}

Uji t digunakan untuk mengetahui tingkat signifikansi variabel independen mempengaruhi variabel dependen secara parsial atau individu (Bawono, 2006). Hasil uji $t_{\text {test }}$ dalam penelitian ini dapat dilihat pada tabel berikut.

Tabel 4.3

Hasil Uji Parsial

\begin{tabular}{cccc}
\hline Variabel & T hitung & T tabel & Kesimpulan \\
\hline \hline & & & \\
Modal & 0,379 & 1,303 & Tidak Berpengaruh \\
Pendampingan & 2,004 & 1,303 & Berpengaruh \\
Pembinaan & 1,812 & 1,303 & Berpengaruh \\
\hline
\end{tabular}

Sumber : Data diolah

Dari tabel coefficients diatas dapat disimpulkan bahwa:

1) Pengaruh modal usaha dengan pendapatan, hipotesisnya adalah sebagai berikut:

H1 : Modal Usaha Program Ekonomi Mandiri berpengaruh signifikan terhadap peningkatan pendapatan usaha mikro mustahik. 


\section{3 | Program Pemberdayaan Ekonomi Mustahik Pada UMKM di Lembaga Zakat Center Kota Cirebon}

Berdasarkan nilai $t_{\text {hitung }}$ sebesar 0,379 dan $t_{\text {tabel }}$ sebesar 1,303, diketahui bahwa $t_{\text {hitung }}<t_{\text {tabel }}$. Dengan demikian keputusannya adalah Ho diterima dan Ha ditolak, artinya modal usaha program ekonomi mandiri tidak berpengaruh signifikan terhadap peningkatan pendapatan usaha mikro mustahik.

2) Pengaruh pendampingan dengan pendapatan, hipotesisnya adalah sebagai berikut:

H2 : Pendampingan program ekonomi mandiri berpengaruh signifikan terhadap peningkatan pendapatan usaha mikro mustahik

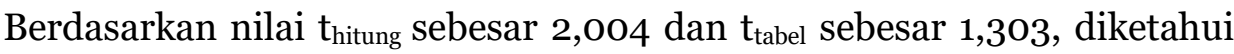
bahwa $t_{\text {hitung }}>t_{\text {tabel, }}$ dengan demikian keputusannya adalah Ho ditolak dan $\mathrm{Ha}$ diterima, artinya pendampingan program ekonomi mandiri berpengaruh signifikan terhadap peningkatan pendapatan usaha mikro mustahik.

3) Pengaruh pembinaan dengan pendapatan, hipotesisnya adalah sebagai berikut:

H3 : Pembinaan program ekonomi mandiri berpengaruh signifikan terhadap peningkatan pendapatan usaha mikro mustahik

Berdasarkan nilai $t_{\text {hitung }}$ sebesar 1,812 dan $t_{\text {tabel }}$ sebesar 1,303, diketahui bahwa $t_{\text {hitung }}>t_{\text {tabel }}$ dengan demikian keputusannya adalah Ho ditolak dan Ha, diterima artinya pembinaan program ekonomi mandiri berpengaruh namun tidak signifikan terhadap peningkatan pendapatan usaha mikro mustahik.

\subsection{Pengujian Secara Simultan}

Uji F digunakan untuk menguji variabel bebas apakah berpengaruh signifikan secara bersama-sama (simultan) terhadap variabel terikat (dependen) yang dalam hal ini yaitu variabel pendapatan. Hasil Uji F ini dapat dilihat pada tabel sebagai berikut:

\section{Tabel 4.4 Uji Secara Simultan}

\begin{tabular}{cccc}
\hline F hitung & F tabel & Sig. & Kesimpulan \\
\hline \hline 5,615 & 2,82 & 0,003 & $\begin{array}{c}\text { Berpengaruh secara } \\
\text { simultan }\end{array}$ \\
\hline
\end{tabular}

Sumber : Data diolah

Hipotesis yang diajukan adalah sebagai berikut:

H4 : Modal usaha, pendampingan dan pembinaan berpengaruh secara simultan signifikan terhadap peningkatan pendapatan usaha mikro mustahik..

Hasil uji $\mathrm{F}$ tersebut menunjukkan bahwa nilai $\mathrm{F}$ hitung sebesar 5.615 dengan nilai Sig sebesar 0,003. Nilai ini kemudian dibandingkan dengan $F_{\text {tabel }}$ yang dihitung 
pada (df pembilang) sebesar 3 dan (df penyebut) sebesar 44 pada taraf 0,05 yang nilainya adalah 2,82 .

Diperoleh bahwa nilai $\mathrm{F}_{\text {hitung }} 5.615>\mathrm{F}_{\text {tabel }}$ 2,82, diketahui pula nilai signifikansi sebesar 0,003 < 0,05, maka Ho ditolak dan Ha diterima, sehingga dapat disimpulkan bahwa variabel modal usaha, pendampingan dan pembinaan berpengaruh secara simultan signifikan terhadap pendapatan usaha mikro mustahik.

\subsection{Analisis Hasil Penelitian}

Penelitian ini bertujuan untuk mengungkap pengaruh modal usaha, pendampingan dan pembinaan terhadap pendapatan usaha mikro mustahik di Zakat Center Thoriqotul Jannah Cirebon, baik secara parsial maupun secara simultan. Hasil pembahasan penelitian ini secara lebih rinci dijelaskan sebagai berikut :

\section{Pengaruh Modal Usaha Terhadap Pendapatan Usaha Mikro Mustahik di Zakat Center Thoriqotul Jannah Cirebon}

Hasil pengujian hipotesis menunjukkan bahwa modal usaha memiliki $t_{\text {hitung }}$ sebesar 0,379 dan $t_{\text {tabel }}$ sebesar 1,303, diketahui bahwa $t_{\text {hitung }}<t_{\text {tabel }}$ dengan taraf signifikansi 0,707 > 0,05, artinya tidak signifikan. Sehingga hipotesis dalam penelitian ini Ha ditolak dan Ho diterima, dengan demikian dapat disimpulkan bahwa modal usaha tidak berpengaruh signifikan terhadap pendapatan usaha mikro mustahik Di Zakat Center Thoriqotul Jannah Cirebon. Hasil penelitian ini sejalan dengan penelitian yang dilakukan oleh Siti Halida Utami (2014), pada penelitiannya menyatakan bahwa dalam pelaksanaan zakat produktif, masih adanya penyalahgunaan bantuan modal usaha yang diberikan dan beberapa mustahik masih menggunakan bantuan tersebut sebagai pemenuhan kebutuhan konsumtif dan kesehatan.

\section{Pengaruh Pendampingan terhadap Pendapatan Usaha Mikro Mustahik di Zakat Center Thoriqotul Jannah Cirebon}

Hasil pengujian hipotesis menunjukkan bahwa pendampingan memiliki $t_{\text {hitung }}$ sebesar 2,004 dan $t_{\text {tabel }}$ sebesar 1,303, diketahui bahwa $t_{\text {hitung }}>t_{\text {tabel }}$ dengan taraf signifikansi $0,052=0,05$, artinya tidak signifikan. Sehingga hipotesis dalam penelitian ini Ha diterima dan Ho ditolak, dengan demikian dapat disimpulkan bahwa pendampingan berpengaruh signifikan terhadap pendapatan usaha mikro mustahik Di Zakat Center Thoriqotul Jannah Cirebon. Hasil penelitian ini sejalan dengan penelitian yang dilakukan oleh Hidayat Aji Pambudi (2012), yang menyimpulkan bahwa pendampingan berpengaruh signifikan terhadap penghasilan mustahik, dengan signifikansi negative, artinya pendampingan yang semakin intensif justru semakin menurunkan penghasilan mustahik, serta pengawasan dan pendampingan tidak berpengaruh secara signifikan terhadap konsumsi, tabungan 


\section{5 | Program Pemberdayaan Ekonomi Mustahik Pada UMKM di Lembaga Zakat}

Center Kota Cirebon

dan infaq mustahik, ini artinya bahwa pengawasan dan pendampingan tidak mempengaruhi tingkat konsumsi, tabungan dan infaq mustahik secara parsial.

\section{Pengaruh Pembinaan Terhadap Pendapatan Usaha Mikro Mustahik di Zakat Center Thoriqotul Jannah Cirebon}

Hasil pengujian hipotesis menunjukkan bahwa modal usaha memiliki $t_{\text {hitung }}$ sebesar 1.812 dan $t_{\text {tabel }}$ sebesar 1,303 , diketahui bahwa $t_{\text {hitung }}>t_{\text {tabel }}$ dengan taraf signifikansi 0,077 > 0,05, artinya tidak signifikan. Sehingga hipotesis dalam penelitian ini Ha diterima dan Ho ditolak, dengan demikian dapat disimpulkan bahwa pembinaan berpengaruh namun tidak signifikan terhadap pendapatan usaha mikro mustahik Di Zakat Center Thoriqotul Jannah Cirebon. Hasil penelitian ini sejalan dengan penelitian yang dilakukan oleh Susi Hendriani dan Soni Nulhaqim, dalam penelitiannya menyimpulkan bahwa pelatihan dan pembinaan mempunyai pengaruh yang signifikan dalam menumbuhkan jiwa wirausaha, artinya lembaga sudah mampu melakukannya dengan maksimal

\section{Pengaruh Modal Usaha, Pendampingan dan Pembinaan terhadap Pendapatan Usaha Mikro Mustahik di Zakat Center Thoriqotul Jannah Cirebon}

Hasil koefisien determinasi menunjukkan bahwa sebesar 23,9\% variasi dari pendapatan usaha mikro mustahik dipengaruhi oleh faktor modal usaha, pendampingan dan pembinaan sedangkan sisanya $76,1 \%$ dijelaskan oleh variabel lain selain dari variabel yang diteliti.

Pengujian hipotesis menunjukkan hasil bahwa nilai $F_{\text {hitung }}$ sebesar 5,615, hasil tersebut kemudian dibandingkan dengan $\mathrm{F}_{\text {tabel }}$ yang diketahui sebesar 2,82. Pada hasil analisis data di atas terlihat $\mathrm{F}_{\text {hitung }}>\mathrm{F}_{\text {tabel}}$, maka dapat disimpulkan bahwa Ho ditolak dan Ha diterima, artinya terdapat pengaruh yang signifikan antara modal usaha, pendampingan dan pembinaan secara bersama-sama terhadap pendapatan usaha mikro mustahik. Hasil penelitian ini sejalan dengan penelitian yang dilakukan oleh Haikal Luthfi Fathullah (2015) yang menghasilkan penelitian bahwa secara simultan dan parsial bantuan modal usaha, pelatihan usaha, pendampingan usaha, dan lama usaha berpengaruh signifikan terhadap pendapatan mustahik.

\section{KESIMPULAN}

Dalam upaya pembinaan program ekonomi mandiri, Zakat Center cukup baik dalam pelaksanaannya namun belum maksimal, dibuktikan dengan sebagian besar responden menjawab setuju dan sangat setuju untuk penyataan-pernyataan pada variable pembinaan, hal ini dikarenakan masih adanya kendala yang dihadapi oleh Zakat Center, salah satunya adalah karena sebagian besar pekerjaan dari mitra binaan adalah berdagang sehingga 
memungkinkan kegiatan pembinaan ini dianggap mengganggu kesibukan mitra binaan, dan setiap pembinaan sekitar 31\% mitra binaan tidak bisa mengikuti pembinaan.

Dalam prakteknya acara pembinaan mengajarkan mitra binaan untuk rutin berinfak dan menabung, sehingga dana infak yang terkumpul dapat digulirkan lagi untuk mustahikmustahik lain yang belum diberdayakan, dalam pembinaan ini mitra binaan diberikan tausiyah keagamaan selain wirausaha dan ekonomi, program ini diharapkan dapat memberikan bekal pengetahuan mitra binaan dalam menjalankan usaha dan kehidupan pribadinya, serta dapat memperluas pemberdayaan usaha-usaha kecil yang dimiliki oleh para mustahik lain, sehingga masalah kemiskinan semakin teratasi.

Program ekonomi mandiri terdiri dari tiga pelaksanaan yaitu pemberian bantuan modal usaha, pendampingan dan pembinaan, ketiganya ini diharapkan dapat saling berkaitan untuk mencapai tujuan dari program ini yakni memberdayakan masyarakat, dan hal ini dapat dibuktikan dari hasil penelitian bahwa secara simultan penyaluran modal usaha, pendampingan dan pembinaan berpengaruh signifikan terhadap pendapatan usaha mikro mustahik di Zakat Center Thoriqotul Jannah Cirebon.

Usaha-usaha kecil terkadang perkembangannya terhambat oleh modal, untuk itu zakat center memberikan penyaluran bantuan modal usaha, namun kembali lagi bahwa usaha tersebut tetap dijalankan oleh mitra binaan sehingga perlu adanya pembinaan untuk memberikan bekal ilmu berwirausaha dan agama. Dalam program ini mitra binaan diwajibkan untuk menabung dan berinfak yang disetorkan kepada Zakat Center setiap bulan pembinaan untuk melatih mustahik agar menjadi seorang muzaki, karena tujuan dari diadakannya program ini adalah untuk memberdayakan masyarakat sehingga usaha-usaha mikro yang dijalankan dapat lebih berdaya.

\section{DAFTAR PUSTAKA :}

\section{Daftar Buku :}

Ghozali, I. (2001). Aplikasi Analisis Multivariate dengan program SPSS, (2nd ed.). Semarang: Universitas Diponegoro.

Sugiyono. (2017). Metode Penelitian Kuantitatif, Kualitatif dan R\&D. Bandung: Alfabeta.

Al-Zuhayly, W. (2008). Al Fiqh Al-Islami Adillatuh (Zakat Kajian Berbagai Madzhab) (terjemahan) (p. PT Remaja Rosyda Karya). Bandung.

Asnaini. (2008). Zakat Produktif dalam Perspektif Hukum Islam. Yogyakarta: Pustaka Pelajar.

Fakhruddin. (2008). Fiqih dan Manajemen Zakat di Indonesia. Malang: UIN-Malang Press.

Hafidhuddin, D. (2002). Zakat dalam Perekonomian Modern. Jakarta: Gema Insani. 


\section{7 | Program Pemberdayaan Ekonomi Mustahik Pada UMKM di Lembaga Zakat}

Center Kota Cirebon

Hasan, M. A. (2006). Zakat dan Infak: Salah Satu Solusi Mengatasi Problema Social Di Indonesia. Jakarta: Kencana Prenada Media Group.

Kamil, M. (2010). Model pendidikan dan pelatihan (Konsep dan Aplikasi). In Model pendidikan dan pelatihan (Konsep dan Aplikasi). Jakarta: Alfabeta.

Kasmir. (2009). Kewirausahaan. Jakarta: Rajawali Pers.

Khasanah, U. (2010). Manajemen Zakat Modern. UIN Maliki Press Malang.

Mas'ud, R. dan M. (2005). Zakat dan Kemiskinan Instrumen Pemberdayaan Ekonomi Umat. Yogyakarta: UII Press.

Mufraini, M. A. (2006). Akuntansi dan Manajemen Zakat. Jakarta: kencana.

Musaddad, M. A. (2006). Zakat Produktif.

Nugraha, A. (2011). Pengaruh Modal Usaha, Tingkat Pendapatan, dan Sikap Kewirausahaan terhadap Pendapatan Usaha Pengusaha Industri. Universitas Negri Yogyakarta.

Qadir, A. (2001). Zakat (dalam Dimensi Mahdah dan Sosial). Jakarta: PT RajaGrafindo Persada.

Qardawi, Y. (2011). Hukum Zakat. Jakarta: Litera Antar Nusa.

Ridwan, M. (2005). Manajemen Baitul Maal Wa Tamwil(BMT),. Yogyakarta: UII Press.

Riyanto. (2001). Pembelanjaan Perusahaan. Yogyakarta: BPFE.

Soemarsono. (2007). Perpajakan: Pendekatan Komprehensif. Jakarta: Salemba Empat.

Supranto, J. (2001). Pengukuran Tingkat Kepuasan Pelanggan (1st ed.). Jakarta: Rineka Cipta.

Suryana. (2003). Kewirausahaan: Pedoman Praktis, Kiat dan Proses Menuju Sukses. Jakarta: Salemba Empat.

Syadam, G. (2006). Built In Training: Jurus Jitu Mengembangankan Propesionalisme Sumebrdaya Manusia. Bandung: Remaja Rosdakarya.

Zain, M. (2008). Manajemen Perpajakan. Jakarta: Salemba Empat.

Labib, M. (2017). Permasalahan Zakat di Indonesia.

Mufraini, M. A. (2008). Akuntansi dan Manajemen Zakat Mengoptimalkan Kesadaran Zakat dan Membangun Jaringan. Jakarta: kencana.

Nasrullah, M. (2006). Peran Zakat Sebagai Pendorong Multiplier Ekonomi. STAIN Pekalongan. 


\section{Daftar Jurnal :}

Amirah. (2012). Zakat produktif sebagai solusi alternatif pengentasan kemiskinan. Studi, Program Perpajakan, Manajemen Ekonomi, Fakultas Tegal, Universitas Pancasakti, 110.

Fathullah, H. L. (2015). PENGARUH BANTUAN ZAKAT PRODUKTIF OLEH LEMBAGA AMIL ZAKAT TERHADAP PENDAPATAN MUSTAHIK (Studi Pada LAZIS Sabilillah dan LAZ El Zawa Malang).

Fathurrohman, N. (2016). Pengaruh Pelatihan, Modal Usaha dan Pendampingan terhadap kesejahteraan mustahik.

Giyanto. (2010). KEBERHASILAN BATIK DI KAMPUNG BATIK KABUPATEN SRAGEN Tesis.

Hendriani, S., \& Nulhaqim, S. A. (2008). Pengaruh Pelatihan dan Pembinaan Dalam Menumbuhkan Jiwa Wirausaha Mitra Binaan PT . ( Persero ) Pelabuhan Indonesia I Cabang Dumai. Kependudukan Padjadjaran, 10(2), 152-168.

Jalaluddin. (2002). Pengaruh Zakat Infaq dan Shadaqah Produktif Terhadap Pertumbuhan Usaha Mikro dan Penerapan Tenaga Kerja Serta Kesejahteraan Mustahik. Majalah Ekonomi, 3 .

Pambudi, A. H. (2012). Peran Zakat Produktif Dalam Pemberdayaan Masyarakat Miskin. Fokus Bisnis, 12(2), 70-80.

Purwanti, E. (2012). Pengaruh Karakteristik Wirausaha, Modal Usaha, Strategi Pemasaran Terhadap Perkembangan UMKM. Among Makarti, 5.

Sartika, M. (2008). Pengaruh Pendayagunaan Zakat Produktif terhadap Pemberdayaan Mustahiq pada LAZ Yayasan Solo Peduli Surakarta. Jurnal La Riba (Jurnal Ekonomi Islam), 2(1), 75-89. $\quad$ Retrieved from http://journal.uii.ac.id/index.php/JEI/article/view/163

Sintha Dwi Wulansari, \& Achma Hendra Setiawan. (2014). Analisis Peranan Dana Zakat Produktif Terhadap Perkembangan Usaha Mikro Mustahik ( Penerima Zakat ). Diponegoro Journal of Economics, 3(1), 1-15.

Utami, S. H., \& Lubis, I. (2013). Pengaruh Pendayagunaan Zakat Produktif Terhadap Pemberdayaan Mustahiq di Kota Medan. Jurnal Ekonomi Dan Keuangan, 2(6), 353366. 